\title{
PENDIDIKAN ISLAM DAN HUMANISME (AKTUALISASI HUMANISME DALAM PENDIDIKAN ISLAM)
}

\author{
Oleh; M. Farid Fad, S.HI., M.SI
}

\begin{abstract}
Abstrak
Aspek mendasar dari pendidikan Islam adalah upaya melahirkan insan kamil. Dunia pendidikan Islam terbebani dengan asumsi positif bahwa pendidikan Islam sebagai suatu kegiatan yang mulia, sakral, mengandung kebijakan, dalam kenyataannya masih jauh dari nilai-nilai kemanusiaan. Akibatnya, pendidikan Islam belum mampu melahirkan sosok manusia yang mengedepankan sisisisi kemanusiaan (humanisme) nya.
\end{abstract}

\section{PENDAHULUAN}

Pendidikan Islam merupakan suatu sistem pendidikan untuk membentuk manusia Muslim sesuai dengan sita-cita Islam. Pendidikan Islam memiliki komponen-komponen yang secara keseluruhan mendukung terwujudnya pembentukan Muslim yang ideal. Oleh karena itu, kepribadian Muslim merupakan esensi sosok manusia yang hendak dicapai (Hadjar, 1999: 3).

Pendidikan merupakan pengenalan dan pengakuan yang secara berangsur-angsur ditanamkan ke dalam manusia tentang tempat-tempat dari segala sesuatu di dalam penciptaan, sehingga dapat membimbing ke arah pengenalan dan pengakuan tempat Tuhan secara tepat di dalam tatanan wujud dan keberadaannya (Ismail, 2002: 52-69).

Muhammad 'Atiyah Al-Abrashy (1970: 15) menerangkan bahwa pendidikan Islam bukanlah sekedar pemenuhan otak saja, tetapi lebih mengarah kepada penanaman akhlak, fadhilah (keutamaan), kesopanan, keikhlasan serta kejujuran bagi peserta didik.

Dengan demikian, pada hakekatnya pendidikan adalah suatu proses "humanisasi" (memanusiakan manusia) yang mengandung implikasi bahwa tanpa pendidikan, manusia tidak akan menjadi manusia dalam arti yang sebenarnya (Ludjito, 1996: 21). 
Menurut M. Rusli Karim (1991: 31), dalam pendidikan Islam, muara pembentukannya mencakup dimensi imanesi (horisontal) dan dimensi transendental (vertikal).

Oleh karena itu, aspek mendasar dari pendidikan Islam adalah upaya melahirkan insan kamil. Dunia pendidikan Islam terbebani dengan asumsi positif bahwa pendidikan Islam sebagai suatu kegiatan yang mulia, sakral, mengandung kebijakan, dalam kenyataannya masih jauh dari nilai-nilai kemanusiaan. Akibatnya, pendidikan Islam belum mampu melahirkan sosok manusia yang mengedepankan sisi-sisi kemanusiaan (humanisme)-nya.

Humanisme dimaknai sebagai potensi (kekuatan) individu untuk mengukur dan mencapai ranah ketuhanan (transendensi) serta mampu menyelesaikan persoalan-persoalan sosial. Menurut Abdurrahman Mas'ud (2002: 135), humanisme dalam pendidikan Islam adalah proses pendidikan yang lebih memperhatikan aspek potensi manusia sebagai makhluk berketuhanan dan makhluk berkemanusiaan serta individu yang diberi kesempatan oleh Allah untuk mengembangkan potensi-potensinya. Disinilah urgensi pendidikan Islam sebagai proyeksi kemanusiaan (humanisasi).

Ironisnya, konsep humanisme dalam dunia pendidikan Islam kurang dikembangkan, indikasinya adalah pendidikan Islam lebih berorientasi pada konsep 'abdullah daripada khalifatullah dan hablum minallah daripada hablum minannas. Orientasi yang timpang ini kemudian melahirkan persoalan filosofis bahkan sampai metodologis (Mas'ud, 2002: 15). Dunia pendidikan Islam kini ---sebagaimana dikemukakan oleh Bassam Tibi yang dikutib Abdul Wahid --sedang mengalami masalah-masalah besar seperti dikotomi (dichotomic), ilmu pengetahuannya yang masih bersifat umum (too general knowledge), maupun rendahnya semangat penelitian (lack of spirit of inquiry) (Tim, 1990: 192). Akibatnya, pendidikan Islam jauh dari penelitian empiris dan disiplin filsafat. Sistem hafalan (memorization) lebih dominan daripada dialog dan rasa ingin tahu. Ide segar, orisinalitas, inovasi dan kreativitas individu menjadi hilang. Bahkan, makna (meaning) menjadi tidak jelas. 
Konsekuensi logis dari berbagai masalah ini adalah pendidikan Islam belum mampu menyentuh ranah kemanusiaan. Bahkan, realitas sosial menjadi terabaikan. Kreativitas individu sebagai manusia unik menjadi terpasung. Dalam bahasa Freire, manusia menjadi tertindas. Selain itu, ajaran Islam menjadi jauh dari penghayatan serta pelaksanaan. Dengan demikian, pendidikan Islam tidak bisa lagi dikatakan bertujuan "memanusiakan manusia", tapi justru menjadi proses "dehumanisasi", sehingga manusia tercabut dari akar kemanusiaannya. Produk dunia pendidikan Islam kini bukan insan kamil, melainkan "manusia yang tidak manusiawi"; manusia yang terpecah kepribadiannya (split personality), dan lebih berorientasi pada "formalitas" sertifikat (certificate oriented) maupun sejenisnya (Tim, 1990: 192).

Berdasarkan latar belakang di atas penulis akan mengkaji tentang pengertian humanisme dalam pendidikan Islam dan aktualisasi humanisme dalam pendidikan Islam.

\section{PEMBAHASAN}

\section{A. Pengertian Humanisme Pendidikan Islam}

Secara etimologi, dalam Kamus Besar Bahasa Indonesia (1990: 192), humanisasi diartikan sebagai penumbuhan rasa perikemanusiaan, pemanusiaan. Sedangkan Chabib Toha (1996: 27) mengartikan:

"Humanisme, kemanusiaan adalah nilai-nilai obyektif yang dibatasi oleh kultur tertentu, nilai kebebasan, kemerdekaan, kebahagiaan. Persamaan hak adalah nilai-nilai kemanusiaan yang dibangun di atas fondasi individualisme dan demokrasi."

Sementara itu istilah di atas banyak berkaitan erat dengan istilah demokratisasi yang bisa diartikan sebagai pembebasan manusia atas ketergantungan terhadap realitas obyektif yang sering menghambat manusia dalam mengembangkan diri untuk mencapai kualitas hidup di luar parameter material. Dan jika ini dikaitkan dengan pendidikan, maka demokratisasi berarti pembebasan pendidikan dan manusia yang terlibat di dalamnya dari struktur dan sistem serta perundangan yang menempatkan manusia sebagai komponen. 
Walaupun istilah-istilah di atas berkonotasi Barat, namun nilainilai tersebut telah diajarkan Islam yaitu tentang penghargaan terhadap eksistensi manusia yang merupakan makhluk beradab, berfikir dan memiliki kesadaran. Di sini Islam dipandang sebagai agama sekaligus sebuah sistem nilai. Dalam konteks pendidikan, Islam menempatkan pendidikan pembebasan yang merupakan refleksi dari pemanusiaan manusia dalam konfigurasi sistem pendidikan Islam yang sangat dipengaruhi oleh prinsip-prinsip kebebasan dan demokrasi.

Secara historis, pendidikan pembebasan telah diterapkan oleh Nabi Muhammad SAW. dalam strategi gerakan dakwah Islam menuju transformasi sosial. Jadi yang dimaksud penulis dengan humanisasi pendidikan Islam adalah pengaplikasian konsep humanisme dalam pendidikan Islam secara riil. Dalam kaitannya dengan ini, Djuwaeli (1998: 78), menjelaskan sebagai berikut;

"pendidikan Islam membentuk keberanian moral bagi setiap peserta didik untuk senantiasa melakukan kegiatan-kegiatan bermanfaat bagi semua manusia dan sebaliknya menghindari perbuatan-perbuatan maksiat yang merugikan orang lain."

\section{B. Aktualisasi Humanisme Dalam Pendidikan Islam}

Secara teoritis, humanisasi dalam kehidupan manusia sangat berkaitan erat dengan gelombang demokratisasi kehidupan manusia pada akhir dekade 80-an. Inti kehidupan demokrasi ialah penghormatan kepada nilai-nilai kemanusiaan. Jadi, gerakan humanisasi dalam dunia pendidikan merupakan sebuah usaha yang lebih mementingkan nilai-nilai kemanusiaan dalam proses pendidikan. Pendidikan dituntut untuk lebih memperhatikan pengembangan kreativitas dalam kepribadian anak (Tilaar, 2001: 4-5).

Menurut Ali Syari'ati (1992: 65-7), pada dasarnya, agama merupakan cinta yang mendorong manusia menuju kesempurnaan dan keselamatan dirinya. Ajaran Lao Tse, Kong Fu Tse, Hinduisme, Yesus Kristus maupun Islam, semuanya menyeru pada pembebasan manusia. 
Konsepsi Islam tentang pembebasan manusia adalah ajaran tauhid yang dibawa oleh Ibrahim, Isa dan Muhammad. Ajaran tauhid menunjukkan bahwa tidak ada penyembahan kecuali kepada Tuhan. Selain itu, ajaran tauhid juga mengandung makna tentang kebebasan manusia. Seseorang yang telah memilih jalan untuk tunduk kepada Tuhan berarti telah menyatakan dirinya untuk lepas dari belenggu apapun (Karim, 1991: 31). Oleh karena itu, Kuntowijoyo (1991: 164-65) berpendapat bahwa misi terbesar dari Islam adalah pembebasan manusia.

Dengan kata lain, Islam adalah agama yang sarat akan kekuatan pembebas (liberating force) bagi manusia. Namun kenyataannya, pendidikan Islam justru masih terkungkung oleh hegemoni Barat. Oleh karena itu, pendidikan Islam pun dituntut untuk menggunakan prinsipprinsip "pembebasan" sebagai wujud nyata dari Islam sebagai agama pembebasan. Jadi, pendidikan Islam adalah "paradigma pembebasan" merupakan sebuah keniscayaan ; condition sine quanon. Diterimanya prinsip dikotomik antara ilmu agama dan ilmu sekuler dalam dunia pendidikan Islam, jelas menunjukkan bahwa fondasi pandangan dasar pendidikan di negara-negara Muslim. Selain itu pun, dikotomi ini diperkuat oleh penjajahan Barat atas dunia Islam yang berlangsung dalam kurun waktu yang cukup lama (Musa, 1991: 18). Dengan demikian, pendidikan Islam--sebagai proses yang disandarkan pada nilai-nilai ideal Islam secara benar dan proporsional--memang seharusnya meletakkan kebebasan manusia sebagai dasar pijakan operasional sekaligus sebagai tujuan pendidikan itu sendiri. Melihat realitas tersebut, nampak jelas bahwa urgensi pendidikan Islam yang dibutuhkan oleh umat dalam masa sekarang ini adalah pendidikan yang mampu menempatkan kekuatan pembebas manusia pada posisi sentral dalam setiap perubahan dan mampu dalam mengendalikan perubahan yang sedang dan akan dialaminya (Khan, 2002: 1-2).

Misi pendidikan Islam yang utama berarti harus membebaskan manusia dari kungkungan dan kejumudan berbagai aliran pemikiran dan 
filsafat yang memandang bahwa manusia tidak mempunyai kemerdekaan.

Menurut Rachmat (2001: 18), rekonstruksi terhadap konsep pendidikan Islam dengan menyertakan konsep Islam merupakan suatu keharusan, sebab Islam memandang manusia dalam wujudnya harus melaksanakan nilai-nilai keagamaan.

Jadi, di saat dunia memasuki era globalisasi--ditandai dengan semakin pentingnya ilmu pengetahuan dan teknologi--yang lebih realistis adalah di samping formulasi dasar pendidikan Islam yang mengacu kepada wahyu, pendidikan Islam pun dituntut untuk selalu merefleksikan serta mereformulasikan konsep ilmu dan kebebasan manusia. Jika rumusan itu lebih spesifik dengan kebutuhan, maka proses pendidikan akan berlangsung dengan dasar pendidikan yang jelas (Khan, 2002: 168).

Pada dasarnya agama (Islam) mempunyai daya dobrak yang efektif untuk membebaskan manusia dari segala keresahan di atas, selama agama (Islam) tidak hanya bergerak pada wilayah normatif dari kondisi riil yang ada.

Humanisme dimaknai sebagai potensi (kekuatan) individu untuk mengukur dan mencapai ranah ketuhanan serta mampu menyelesaikan persoalan-persoalan sosial. Sementara itu, pendidikan Islam merupakan suatu proses dalam pembentukan manusia sesuai dengan cita-cita Islam. Dengan demikian, humanisme dalam dunia pendidikan Islam merupakan proses pendidikan yang lebih memperhatikan aspek potensi manusia sebagai makhluk berketuhanan dan makhluk berkemanusiaan serta individu yang diberi kesempatan oleh Allah untuk mengembangkan potensi-potensinya (Mas'ud, 2002: 135).

Oleh karena itu, humanisasi dalam dunia pendidikan menuntut proses pendidikan yang lebih memperhatikan pengembangan kreativitas dalam kepribadian peserta didik sebagai inti dari kehidupan demokratis yang sangat menghormati nilai-nilai kemanusiaan (Tilaar, 2001: 4-5). Jadi, gerakan humanisasi dalam dunia pendidikan merupakan sebuah 
usaha yang lebih mementingkan nilai-nilai kemanusiaan dalam proses pendidikan. Pendidikan dituntut untuk lebih memperhatikan pengembangan kreativitas dalam kepribadian peserta didik.

Menurut Muhaimin Iskandar (2000: 187), dalam catatan epilog pada buku Paulo Freire, Islam dan Pembebasan”, mengemukakan bahwa konsep tauhid seharusnya tidak bisa hanya dipahami sebagai pandangan tentang keesaan Allah, tetapi juga bermakna bahwa manusia hanya tunduk kepada yang satu, dan tidak boleh ada kekuatan lain yang dapat menaifkan kemuliaan dan kebebasan manusia yang fitrah, kecuali Allah. Tauhid secara logis juga dapat diartikan bahwa penciptaan adalah esa. Ia menolak segala bentuk diskriminasi berdasarkan ras, warna kulit, kelas, garis keturunan, kekayaan dan kekuasaan.

Jadi kebebasan manusia merupakan fitrah, walaupun sifatnya relatif. Karena hanya Allah-lah yang mempunyai kebebasan mutlak. Uraian di atas sedikit telah memberi gambaran tentang konsep pembebasan manusia melalui pendidikan Islam itu sendiri yaitu menjadikan manusia sebagai 'abdullah sekaligus khalifatullah melalui proses pemeliharaan dan penguatan sifat dan potensi insani sehingga dapat menumbuhkan kesadaran untuk menemukan kebenaran.

Lebih lanjut, di bawah ini akan dibahas beberapa hal yang dapat dijadikan landasan atau titik tolak dari humanisasi pendidikan Islam, yaitu apa yang diistilahkan oleh Abdurrahman Mas'ud (2003: 144-153), sebagai motif dan paradigma lama yang masih menggejala dalam sistem pendidikan Islam. Beberapa hal tersebut antara lain:

1. Keberagamaan yang cenderung menekankan hubungan vertikal dan kesemarakan ritual

2. Kesalehan sosial agaknya masih jauh dari orientasi masyarakat

3. Potensi peserta didik belum dikembangkan secara proporsional, pendidikan belum berorientasi pada pengembangan sumber daya manusia atau belum individual-oriented 
4. Kemandirian anak didik dan tanggung jawab (responsibility) masih jauh dalam capaian dunia pendidikan.

Menurut Abdurrahman Mas'ud paling tidak ada enam hal pokok sebagai basic principle yang perlu dikembangkan lebih lanjut dalam pendidikan Islam, yaitu: "common sense, akal sehat, individualisme menuju kemandirian, thirst for knowledge, pendidikan pluralisme, kontekstualisme yang lebih mementingkan fungsi daripada simbol serta keseimbangan antara reward and punishment."

Manusia sebagai makhluk yang multidimensi, mempunyai beberapa tanggung jawab yang terkait dengan segala aspek dengan dirinya. Pertama, tanggung jawab kepada Tuhan Yang Maha Esa dengan jalan beribadah kepada-Nya sebagai ungkapan rasa syukur. Hal ini sangat inheren dengan fitrah kejadian manusia. Kedua, tanggung jawab manusia terhadap dirinya sendiri dalam rangka mengembangkan kapasitas potensialnya. Hal ini bisa dilaksanakan melalui pendidikan yang berorientasi kepada masa yang akan datang demi peningkatan kualitas hidup. Ketiga, tanggung jawab kepada masyarakat melalui peningkatan kualitas pribadi. Keempat, tanggung jawab manusia terhadap alam semesta. Hal ini sebagai konsekuensi dari ketiga tanggung jawab di atas, karena alam merupakan sarana hidup masyarakat yang diciptakan Tuhan.

Hal ini senada dengan apa yang dinamakan Freire sebagai konsep "praxis" yaitu rangkaian kegiatan pendidikan yang diberikan kepada orang agar mau dan mampu mengambil sikap dan melakukan perbuatan, setelah ia mengadakan pengukuran dan penilaian terhadap dirinya sendiri (reflective thinking) (Sarwoko, 1989: 23). Dengan aksi dan refleksi otentik inilah manusia bisa melakukan transformasi realitas yang menindas, mendominasi dan dehumanis menuju pembebasan serta humanisasi.

Misalnya, pendidikan kebersihan dalam Islam, seharusnya tidaklah hanya dengan menggunakan pesan-pesan melalui tulisan “Kebersihan Sebagian Dari Iman” atau “ An-Nadzofatu minal Imaan”, 
tetapi yang jauh lebih penting adalah penerapan dari pesan-pesan tersebut dalam kehidupan sehari-hari. Dan masih banyak lagi praktek-praktek pendidikan yang belum fungsional, sebagaimana dicontohkan Abdurrahman Mas'ud yaitu pendidikan bahasa yang seharusnya menjadi seperangkat kebiasaan dan alat komunikasi, tetapi dalam kenyataannya, bahasa hanya menjadi materi pelengkap pendidikan yang lebih banyak dipelajari dari segi struktur, grammar serta tata bahasanya saja.

Lebih lanjut Mas'ud (2003: 185-86) menjelaskan tentang beberapa prinsip dalam rangka melaksanakan konsep di atas (reward and punishment) secara seimbang, antara lain pertama, kesabaran, keuletan dan ketegarannya dalam menegakkan ajaran Islam. Kedua, pemaaf, tanpa dendam dan dengki kepada orang lain yang berbuat salah kepadanya. Ketiga, mencintai dan menyayangi sesama mukmin.

Jadi, pendidikan merupakan perjuangan dalam melawan dominasi dikotomis antara dimensi ketuhanan dan kemanusiaan dalam dunia pendidikan. Dengan demikian, kedua tokoh ini telah melakukan "ijtihad intelektual" untuk membebaskan manusia dari budaya verbal yang serba naif dan membosankan dalam proses pendidikan yang mematikan daya kritis dan daya kreatif manusia. Dengan kata lain, kedua tokoh ini telah berusaha menghidupkan pengalaman "demokrasi" dalam dunia pendidikan. Inti kehidupan demokrasi ialah penghormatan kepada nilainilai kemanusiaan. Jadi, tanpa penerapan asas demokrasi, tidak mungkin kreativitas yang menjadi sumber bagi peningkatan hidup manusia dapat hidup dan berkembang (Tilaar, 2001: 4-5).

Sedangkan implementasi humanisme dalam pendidikan Islam tidak akan terlepas dari beberapa komponen pendidikan yang ikut andil dalam menentukan berhasil tidaknya usaha ini. Di bawah ini akan dipaparkan komponen-komponen tersebut secara terperinci.

1. Pendidik

Pendidik merupakan salah satu aspek yang penting dalam sebuah sistem pendidikan. Dalam konsep humanisasi pendidikan 
Islam, pendidik bukanlah tokoh utama dalam proses pembelajaran, yang dapat mendominasi forum. Tidak dibenarkan pula seorang pendidik melakukan diskriminasi vertikal antara pendidik tersebut dan peserta didik, sehingga akan memunculkan silence culture, kebudayaan bisu (meminjam istilahnya Paulo Freire).

Apalagi praktek-praktek domestikasi pendidik yang merupakan penindasan dan cenderung membendung inisiatif, kreatifitas, inovasi peserta didik, yang disebut Freire sebagai banking system atau bank concept (Sarwoko, 1989: 23).

Seorang pendidik, seyogyanya selalu meningkatkan interaksi, menciptakan kondisi forum sehingga terbina partisipasi aktif dari peserta didik serta memberikan kesempatan seluas-luasnya untuk mengembangkan potensi masing-masing individu. Sehingga fungsi pendidik di sini hanya sebagai inovator dan motivator (Nurdin, 2003: 24-5).

Jelasnya, pendidik haruslah membudayakan komunikasi dua arah, sehingga akan tercipta suasana yang demokratis dalam proses pembelajaran.

2. Metode

Setiap sistem pendidikan tentu saja mempunyai tujuan tertentu sesuai dengan paradigma yang dipakai. Untuk dapat mencapai tujuan tersebut diperlukan beberapa komponen pendukung, Salah satunya adalah metode yang diterapkan dalam proses pembelajaran.

Dalam konsep humanisasi pendidikan Islam, sudah tidak layak lagi seorang pendidik yang menggunakan paradigma lama dalam rangka mengaplikasikan suatu metode tertentu yaitu dengan menganggap peserta didik sebagai obyek pembelajaran yang harus mendapat masukan ilmu terus-menerus tanpa mempedulikan berbagai potensi yang dimiliki oleh peserta didik. Sebagai makhluk yang diciptakan Allah dengan dua jabatan sekaligus (yakni Abdullah dan Khalifatullah), peserta didik merupakan individu yang utuh, sehingga 
metode yang tepat seyogyanya adalah metode yang dapat mengembangkan potensi-potensi tersebut dalam rangka merekatkan baik keterhubungan dengan Tuhan, hablum minallah, maupun keterhubungan dengan sesama manusia, hablum minannas, di mana keduanya merupakan pengejawantahan dari peran Abdullah dan Khalifatullah tersebut. Menurut Mas'ud (2003: 197-202), untuk mencapai tujuan tersebut, diperlukan suatu proses becoming dan educating bagi peserta didik serta proses liberating, dan civilizing bagi pendidik, dimana yang menjadi sasaran utama adalah proses humanisasi dalam pembelajaran tersebut.

Menurut hemat penulis, metode yang sesuai dengan kerangka ini harus didasarkan pada komunikasi dialogis, misalnya diskusi, dialog, bermain peran dan sebagainya. Dengan metode ini, peserta didik diajarkan untuk berani menyampaikan pendapat, menilai baik dan buruk serta mengajak siswa untuk sampai pada discovery. Pada akhirnya, penerapan metode di atas akan dapat membentuk peserta didik yang tidak minder, aktif, kreatif, inovatif, serta mempunyai semangat yang tinggi dalam meneliti.

Tentu saja pelaksanaannya disesuaikan dengan perkembangan akal dan kemampuan berpikir siswa. Hal ini dikaitkan dengan materi yang akan dibahas kemudian.

\section{Peserta Didik}

Peserta didik merupakan subjek pendidikan, karena merekalah yang belajar, memiliki tujuan dan pewaris masa depan. Sedangkan pendidikan ibarat sebuah busur panah, tempat mengarahkan peserta didik menuju sasaran itu. Peserta didik atau yang kita kenal dengan sebutan murid, dalam bahasa Arab yang artinya pencari (ilmu). Hal ini menunjukkan adanya peran aktif dari peserta didik tersebut dalam proses pembelajaran.

Hal ini diperkuat pula dengan adanya peran utama peserta didik sebagai manusia di muka bumi sebagai khalifah, sehingga mereka 
memiliki sejumlah kemampuan untuk memilih dan bertindak, walaupun sifatnya tidak mutlak.

Dengan kedua paradigma ini diharapkan pendidikan akan menunjukkan fungsi aslinya sebagai media dalam membebaskan manusia dari segala bentuk dominasi dan alienasi, serta mengembangkan segala potensi manusia itu sebagai proses humanisasi. Hal ini akan mudah dicapai dengan adanya komunikasi dan motivasi dalam sebuah proses pembelajaran. Pendidikan bisa berlangsung dengan baik, manakala di dalamnya terjadi komunikasi timbal balik (two ways communication) antara pendidik dan peserta didik. Dengan komunikasi ini pendidik tidak dapat memaksakan pikirannya kepada peserta didik. Karena pemaksaan apapun jenisnya, tidak akan mampu menggali dan menumbuhkan motivasi belajar pada peserta didik. Dengan pemaksaan ini pula, peserta didik hanya diajari untuk beradaptasi bukannya berintegrasi.

Kondisi semacam ini (dimulai dari dialog hingga penumbuhan motivasi yang pada akhirnya berimplikasi pada pengintegrasian), akan menciptakan interaksi pendidikan dimana pendidik dan murid samasama menjunjung tinggi nilai-nilai demokratis dan manusiawi. Hal yang demikian dapat menumbuhkan kepercayaan diri, karena hidupnya terasa bermakna, serta apa yang mereka hasilkan tidak sia-sia, melainkan mendapat penghargaan yang setimpal.

4. Materi

Salah satu aspek penting dalam pendidikan adalah materi. Materi yang akan disajikan dalam sebuah proses pembelajaran, sebaiknya disesuaikan dengan tujuan pendidikan itu sendiri. Selain itu, kondisi peserta didik, pengajar, sarana, metode dan sebagainya yang memungkinkan dalam melaksanakan atau mengkaji materi tersebut. Maka isi atau materi pelajaran dapat diidentikkan dengan proses belajar. 
Materi pendidikan dalam kerangka humanistik harus mencakup dimensi teori sekaligus praktek. Jadi materi bukan berupa ide-ide inersia (meminjam istilah Alfred) yaitu ide-ide yang semata-mata hanya diterima di dalam pikiran tanpa digunakan atau diuji atau diolah menjadi kombinasi yang segar.

Di bawah ini, menurut Qodry A. Azizy (2002: 31-3), akan diuraikan empat visi dasar pendidikan yang dirumuskan oleh UNESCO. Dimana visi tersebut dapat dijadikan landasan dalam pemilihan materi yaitu:

a. Learning to think (belajar bagaimana berpikir)

b. Learning to do (belajar bagaimana berbuat)

c. Learning to be (belajar bagaimana tetap hidup atau sebagai dirinya)

d. Learning to live together (belajar untuk hidup bersama-sama).

Dengan berlandaskan pada empat visi di atas, materi pendidikan Islam dapat mencakup segala sendi kehidupan. Selanjutnya beberapa hal di bawah ini perlu juga menjadi bahan pertimbangan dalam penentuan materi belajar, yaitu

a. Materi ditekankan pada hal-hal yang dapat meningkatkan semangat diskusi peserta didik,

b. Materi berorientasi kepada penelitian-penelitian dan bukan hanya berupa bahan hafalan,

c. Materi terkait dengan problem-problem siswa di lingkungannya sehingga tidak hanya berupa prinsip-prinsip atau teori-teori yang melangit.

Materi yang memperhatikan beberapa hal di atas demikian lebih efektif dalam rangka pengembangan segala potensi baik dari segi kognitif, afektif, juga psikomotorik peserta didik dalam hubungannya dengan Tuhan, sesama manusia dan juga alam sekitarnya.

5. Evaluasi

Dalam sistem humanisasi pendidikan Islam tidak mengenal adanya diskriminasi serta dominasi dari satu pihak ke pihak terhadap 
pihak yang lain (misalnya seorang pendidik terhadap peserta didik). Keduanya merupakan individu yang sama-sama mempunyai tanggung jawab sebagai Khalifatullah dan 'Abdullah. Dalam pandangan Islam, prinsip egalitarian merupakan pengejawantahan dari kenyataan tauhid dimana kedudukan manusia di hadapan Tuhan adalah sama, dan pada hakikatnya manusia adalah satu, karena berasal dari Yang Maha Esa.

Implementasi konsep tersebut dalam evaluasi pendidikan tercermin dengan adanya evaluasi dua arah antara pendidik dan peserta didik. Hal ini dikarenakan keduanya berada dalam "gerbong" pembelajaran yang sama, untuk menuju tujuan yang sama pula. Jadi mereka merupakan mitra yang sama-sama mempunyai kepribadian, tanggung jawab, hak asasi, sehingga terdapat konsekuensi untuk saling mengevaluasi di antara keduanya.

Oleh karena tujuan pendidikan Islam sebagaimana disinggung pada uraian-uraian sebelumnya adalah upaya mewujudkan individu secara holistik, insan kamil dalam segala aspek, potensi dan sebagainya yang dimiliki, maka evaluasi yang diberlakukan juga harus menyentuh segala hal tersebut.

Evaluasi tidak boleh menafikan salah satu domain dalam proses pembelajaran. Jadi, selain domain kognitif, kedua domain lainnya yakni afektif dan psikomotorik juga turut dievaluasi. Selain itu berbagai kecerdasan yang dimiliki individu-individu, baik kecerdasan intelektual, emosional maupun spiritual pun tidak boleh terlupa dari proses evaluasi.

Hal lain yang perlu diperhatikan dalam proses evaluasi yaitu bahwa evaluasi tidak hanya dilakukan sekali pada waktu tertentu saja, tetapi harus dilakukan secara terus menerus (continue) dan berkesinambungan serta dimanapun proses tersebut dilaksanakan. Hal ini menandakan bahwa proses atau means lebih penting daripada tujuan (Mas'ud, 2003: 213). 


\section{KESIMPULAN}

Pendidikan humanisme merupakan pendidikan yang memposisikan manusia pada fitrahnya dengan kebebasan yang dimilikinya untuk mengembangkan dan mengaktualisasikan segala potensi yang dimilikinya dalam memahami ajaran Islam. Dengan humanisme yang diterapkan dalam pendidikan Islam maka kreativitas dari peserta didik dapat dibentuk dengan baik, karena mereka memahami agamanya bukan karena dogma akan tetapi karena proses pencarian pemahaman (verstehen) yang mendalam dari pendidikan agama yang diberikan.

Makna humanisme sebagai ajaran dan pandangan hidup, menurut hemat penulis, harus direformulasi sesuai dengan konteks yang dinamis. Humanisme harusnya bukanlah dimaknai sebagai ajaran statis, akan tetapi ajaran 'proses menjadi' manusia yang terus berkembang dalam relasi sosialnya (social relationship).

Pendidikan oleh humanisme dimaknai sebagai proses penyempurnaan diri sebagai manusia, dengan kata lain merupakan proses pemberadaban (civilized). Artinya, pendidikan yang humanis tidak hanya mendidik "menjadi manusia", lebih tepatnya, mendidik manusia agar berkebudayaan lebih tinggi.

Penerapan humanisme dalam pendidikan Islam sangatlah urgen guna membuktikan Islam sebagai ajaran rahmat lil 'alamin, sekaligus memupuk rasa empati dan simpati terhadap sesama manusia, karena pada prinsipnya, praktek pendidikan Islam yang humanis adalah memanusiakan manusia sesuai perannya sebagai khalifah di muka bumi. 


\section{DAFTAR KEPUSTAKAAN}

Al-Abrashy, Muhammad 'Atiyah, Dasar-dasar Pendidikan Islam, Jakarta: Bulan Bintang, 1970.

Azizy, Qodri A., Pendidikan (Agama) untuk Membangun Etika Sosial, Semarang, Aneka Ilmu, 2002.

Chabib Thoha, dkk., Metodologi Pengajaran Agama, Yogyakarta: Kerjasama Fak. Tarbiyah IAIN Walisongo Semarang dengan Pustaka Pelajar 1999.

Djuwaeli, Irsjad, Pembaruan Kembali Pendidikan Islam, Jakarta, Karsa Utama Mandiri dan PB Mathla'ul Anwar, 1998.

Iskandar, Muhaimin, dalam Muh. Hanif Dzakiri, Paulo Freire, Islam dan Pembebasan, Jakarta, Penerbit Pena dan Penerbit Djambatan, 2000.

Hadjar, Ibnu, 1999, ("Pendekatan Keberagamaan dalam Pemilihan Metode Pengajaran Pendidikan Agama Islam") dalam Chabib Thoha, dkk., Metodologi Pengajaran Agama, Yogyakarta: Kerjasama Fak. Tarbiyah IAIN Walisongo Semarang dengan Pustaka Pelajar.

Ismail SM, "Konsep Pendidikan Islam; Studi Pemikiran Pendidikan Syeh Muhammad Naquib al-Attas" Tesis Pascasarjana IAIN Walisongo Semarang, (Semarang: Perpustakaan Pascasarjana IAIN Walisongo Semarang, 2002).

Karim, M. Rasuli, "Pendidikan Islam Sebagai Upaya Pembebasan Manusia", dalam Muslih Musa (ed.), Pendidikan Islam di Indonesia Antara Cita dan Fakta, (Yogyakarta: Tiara Wacana, 1991).

Khan, Achmad Warid, Membebaskan Pendidikan Islam, Yogyakarta: Kerjasama Institut Tafsir Wacana (ISTAWA) dengan penerbit Wacana, 2002.

Kuntowijoyo, Paradigma Islam; Interpretasi Untuk Aksi, Bandung: Mizan, 1991.

Ludjito, Ahmad, "Filsafat Pendidikan dalam Islam" dalam Chabib Toha, dkk, Reformasi Filsafat Pendidikan Islam, Yogyakarta: Pustaka pelajar, 1996.

Mas'ud, Abdurrahman, Menggagas Format Pendidikan Nondikotomik; Humanisme Religius Sebagai Paradigma Pendidikan Islam, Yogyakarta: Gama Media, 2002.

, Menuju Paradigma Islam humanis, Yogyakarta: Gama Media, 2003. 
Musa, Muslih (ed.), Pendidikan Islam di Indonesia Antara Cita dan Fakta, Yogyakarta: Tiara Wacana, 1991.

Nurdin, Syafruddin dan M. Basyiruddin Usman, Guru profesional dan Implementasi Kurikulum, Jakarta, Ciputat Press, 2003.

Rachmat, Jalaludin, Teologi Pendidikan, Jakarta: Rajawali Grafindo Persada, 2001.

Sarwoko, Bambang, Konsep Dasar Pendidikan Luar Sekolah, Cet. I, Semarang, IKIP Semarang Press, 1989.

Syari'ati, Ali, Humanisme Antara Islam dan Madzhab Barat, Bandung: Pustaka Hidayah, 1992.

Thoha, Chabib, Kapita Selekta Pendidikan Islam, Yogyakarta, Pustaka Pelajar, 1996.

Tilaar, H.A.R., Manajemen Pendidikan Nasional ; Kajian Pendidikan Mada Depan, Bandung: PT Remaja Rosdakarya, 2001, Cet. V.

Tim Penyusun Kamus Pusat Pembinaan dan Pengembangan Bahasa, Kamus Besar Bahasa Indonesia, Cet. 3, Jakarta, 1990. 